\title{
OPTIMALISASI PROSES DAN HASIL PEMBELAJARAN ILMU PENGETAHUAN ALAM (IPA) PADA SEKOLAH DASAR (SD)/ MADRASAH IBTIDAIYAH (MI)
}

\author{
Irjan \\ Staf Pengajar pada PGMI Fakultas Tarbiyah UIN Malang)
}

\begin{abstract}
The survey result of International Monitoring Studies has done by TIMSS (Third International Science and Mathematics Study) at 2005 in science education domain (1) Analysis of content structure, (2) Research on teaching and learning, (3) Development and evaluation of instruction/Instructional design, dan (4) Research on curriculer issue and science education policies, has reported that quality of science (IPA) learning in Indonesia is still leaved than others state in Asia, even Asia Tenggara. Therefore, we should evaluate totality concerning with learning process of science, especially in SD/MI and the steps concretely which is able to perform to identify a variety of obstacle of science learning and his solution with the result that is able to increase the process and the result of science learning at SD/MI
\end{abstract}

Keyword: Learning, Science, SD/MI

\section{A. Latar Belakang}

Ilmu Pengetahuan Alam (IPA) berhubungan dengan cara mencari tahu tentang alam secara sistematis, sehingga IPA bukan hanya penguasaan kumpulan pengetahuan yang berupa fakta-fakta, konsepkonsep, atau prinsip-prinsip saja tetapi juga merupakan suatu proses penemuan. Pendidikan IPA diharapkan dapat menjadi wahana bagi peserta didik untuk mempelajari diri sendiri dan alam sekitar, serta prospek pengembangan lebih lanjut dalam menerapkannya di dalam kehidupan sehari-hari. Proses pembelajarannya menekankan pada pemberian pengalaman langsung untuk mengembangkan kompetensi agar menjelajahi dan memahami alam sekitar secara ilmiah. Pendidikan IPA diarahkan untuk inkuiri dan berbuat sehingga dapat membantu peserta didik untuk memperoleh pemahaman yang lebih mendalam tentang alam sekitar.

IPA diperlukan dalam kehidupan sehari-hari untuk memenuhi kebutuhan manusia melalui pemecahan masalah-masalah yang dapat diidentifikasikan. Penerapan IPA perlu dilakukan secara bijaksana agar tidak berdampak buruk terhadap lingkungan. Di tingkat SD/MI diharapkan ada penekanan pembelajaran Salingtemas (Sains, lingkungan, teknologi, dan masyarakat) yang diarahkan pada pengalaman belajar 
untuk merancang dan membuat suatu karya melalui penerapan konsep IPA dan kompetensi bekerja ilmiah secara bijaksana.

Pembelajaran IPA sebaiknya dilaksanakan secara inkuiri ilmiah (scientific inquiry) untuk menumbuhkan kemampuan berpikir, bekerja dan bersikap ilmiah serta mengkomunikasikannya sebagai aspek penting kecakapan hidup. Oleh karena itu pembelajaran IPA di SD/MI menekankan pada pemberian pengalaman belajar secara langsung melalui penggunaan dan pengembangan keterampilan proses dan sikap ilmiah.

Standar Kompetensi (SK) dan Kompetensi Dasar (KD) IPA di SD/MI merupakan standar minimum yang secara nasional harus dicapai oleh peserta didik dan menjadi acuan dalam pengembangan kurikulum di setiap satuan pendidikan. Pencapaian SK dan KD didasarkan pada pemberdayaan peserta didik untuk membangun kemampuan, bekerja ilmiah, dan pengetahuan sendiri yang difasilitasi oleh guru.

Tulisan ini mencoba memaparkan bagaimana cara pembelajaran IPA sehingga diperoleh proses dan hasil pembelajaran yang optimal pada siswa SD/MI. Rasionalisasi dari tulisan ini, menganut paham konvergensi yang mengemukakan bahwa didalam perkembangan individu, baik faktor bawaan sejak lahir (faktor dasar) maupun faktor lingkungan memainkan peranan penting. Bakat kemungkinan telah ada pada masing-masing individu, akan tetapi bakat yang tersedia itu perlu menemukan lingkungan yang sesuai supaya dapat berkembang maksimal. Banyak diantara hasilhasil penelitian yang mengungkapkan bahwa untuk menghantarkan individu menjadi dewasa diperlukan suatu proses belajar dan pembelajaran yang memadai.

Untuk menuju kepada proses belajar dan hasil pembelajaran IPA yang optimal, maka penulis membangun sebuah gagasan dengan kerangka berpikir meliputi: (a) Bagaimana belajar dan pembelajaran IPA di SD/MI? (b) Apa tujuan belajar dan pembelajaran IPA diSD/MI? (c) Apa saja ruang lingkup materi pembelajaran IPA di SD/MI? (d) Bagaimana langkah-langkah pembelajaran IPA di SD/MI?, dan (e) Bagaimana tehnik evaluasi belajar dan pembelajaran IPA di SD/MI?.

\section{B. Belajar dan Pembelajaran IPA di SD/MI}

Apakah belajar itu?. Cronbach didalam bukunya: Educational Psychology menyatakan bahwa: learning is shown by a change in behavior as a result of experience dalam (Sanjaya, 2007). Dengan kata lain, belajar ditunjukkan oleh perubahan sikap sebagai hasil dari pengalaman seseorang. Ditinjau dari sudut pandang IPA, belajar dapat dimaknai sebagai proses melibatkan manusia secara orang per orang sebagai satu kesatuan organisme sehingga terjadi perubahan pada pengetahuan, keterampilan dan sikap. Sementara itu, pembelajaran IPA dimaknai sebagai proses yang diselenggarakan oleh guru untuk membelajarkan 
siswa dalam belajar IPA bagaimana belajar memperoleh pengetahuan, keterampilan dan sikap.

Dari pengertian belajar dan pembelajaran IPA di atas, maka dapat diidentifikasikan dua aspek penting. Aspek pertama, adalah hasil belajar yakni perubahan prilaku pada diri siswa. Aspek kedua, adalah proses belajar yakni sejumlah pengalaman intelektual, emosional dan fisik pada diri siswa dalam menghadapi bahan ajar.

Bertolak dari kedua aspek di atas, maka kegiatan pembelajaran IPA di sekolah haruslah "membelajarkan siswa bagaimana belajar IPA". Tujuan pokoknya adalah meletakkan landasan bagi belajar seumur hidup. Hal ini berkaitan dengan berbagai temuan penelitian yang menyebutkan bahwa "fakta-fakta, prinsip, dan konsep IPA" seringkali berumur pendek, karena dominasi peran guru sebagai satu-satunya komunikator. Oleh karena itu, tujuan pokok penyelenggaraan kegiatan pembelajaran IPA di sekolah secara operasional adalah membelajarkan siswa agar mampu memproses dan memperoleh pengetahuan, keterampilan, dan sikap ilmiah bagi dirinya sendiri.

IPA dibangun melalui prosedur metodologi ilmiah. Jadi idealnya tidak ada pengetahuan (fakta-fakta, prinsip dan konsep) dan sejumlah keterampilan proses dalam IPA yang diperoleh tanpa melalui prosedur metodologi ini. Tahapan atau prosedural dalam menemukan fakta, prinsipprinsip dan konsep dalam IPA meliputi:

1. Melakukan observasi dan pengukuran secara akurat.

2. Mengajukan suatu hipotesis (dugaan sementara) untuk masalah yang dirumuskan.

3. Merancang penelitian sederhana untuk menguji apakah hipotesis tersebut benar.

4. Memproses data dan membuat kesimpulan.

5. Mengkomunikasikan informasi secara efektif baik secara verbal maupun nonverbal.

6. Perumusan hukum ilmiah. (Saktiyono,2007)

C. Tujuan Belajar IPA di SD/MI

Tujuan umum pembelajaran IPA di SD/MI adalah agar peserta didik memiliki kemampuan sebagai berikut.

1. Memperoleh keyakinan terhadap kebesaran Tuhan Yang Maha Esa berdasarkan keberadaan, keindahan dan keteraturan alam ciptaan-Nya

2. Mengembangkan pengetahuan dan pemahaman konsep-konsep IPA yang bermanfaat dan dapat diterapkan dalam kehidupan sehari-hari 
3. Mengembangkan rasa ingin tahu, sikap positip dan kesadaran tentang adanya hubungan yang saling mempengaruhi antara IPA, lingkungan, teknologi dan masyarakat

4. Mengembangkan keterampilan proses untuk menyelidiki alam sekitar, memecahkan masalah dan membuat keputusan

5. Meningkatkan kesadaran untuk berperanserta dalam memelihara, menjaga dan melestarikan lingkungan alam

6. Meningkatkan kesadaran untuk menghargai alam dan segala keteraturannya sebagai salah satu ciptaan Tuhan

7. Memperoleh bekal pengetahuan, konsep dan keterampilan IPA sebagai dasar untuk melanjutkan pendidikan ke SMP/MTs. (UU No. 20 tahun 2003).

Tujuan belajar penting bagi guru dan siswa sendiri. Dalam desain instruksional, guru diharapkan dapat menjabarkan tujuan pembelajaran/ instruksional umum ke dalam tujuan instruksional khusus atau sasaran belajar siswa. Rumusan tersebut disesuaikan dengan prilaku yang hendaknya dapat dilakukan siswa. Dalam klasifikasi tujuan pendidikan, tujuan pembelajaran/instruksional merupakan tujuan yang paling khusus. Tujuan pembelajaran adalah kemampuan (kempetensi) atau keterampilan yang diharapkan dapat dimiliki oleh siswa setelah melakukan pembelajaran tertentu.

Dalam merumuskan tujuan pembelajaran IPA maka sebaiknya memperhatikan empat komponen pokok yang harus nampak dalam indikator hasil belajar, yaitu Audience (siapa yang harus memiliki kemampuan), Behavior (prilaku yang bagaimana yang diharapkan dapat dimiliki), Condition (dalam kondisi dan situasi yang bagaimana subjek dapat menunjukkan kemampuan sebagai hasil belajar yang telah diperolehnya), Degree (kualitas dan kuantitas tingkah laku yang diharapkan dicapai sebagai batas minimum).

Dengan mengacu kepada keempat komponen pokok sebagaimana disebutkan di atas, maka rumusan tujuan pembelajaran/Instruksinal khusus dapat diilustrasikan sebagai berikut, misalnya:

a) Siswa kelas $6 \mathrm{SD} / \mathrm{MI}$ diharapkan dapat mendefenisikan sel, jaringan dan organ (komponen Audience)

b) Dapat mengungkapkan langkah-langkah pengamatan sel sebagai bagian dari organ tubuh manusia dengan menggunakan mikroskop (komponen Behavior)

c) Melalui media gambar yang ditunjukkan kepadanya dapat menunjukkan tata letak organ tubuh manusia bagian dalam (komponen Condition) 
d) Dapat menyebutkan urutan komponen-komponen penyusun tubuh manusia dari ukuran yang paling kecil sampai kepada ukuran yang paling besar (komponen Degree).

e) Dapat menyebutkan cara-cara merawat sel, jaringan dan organ pada tubuh manusia (komponen Behavior).

\section{Ruang Lingkup Pembelajaran IPA di SD/MI}

Ruang Lingkup bahan kajian IPA untuk SD/MI meliputi aspekaspek berikut:

1. Makhluk hidup dan proses kehidupan, yaitu manusia, hewan, tumbuhan dan interaksinya dengan lingkungan, serta kesehatan.

2. Benda/materi, sifat-sifat dan kegunaannya meliputi: cair, padat dan gas.

3. Energi dan perubahannya meliputi: gaya, bunyi, panas, magnet, listrik, cahaya dan pesawat sederhana.

4. Bumi dan alam semesta meliputi: tanah, bumi, tata surya, dan bendabenda langit lainnya.

Dari semua kajian yang meliputi keempat aspek di atas diharapkan siswa SD/MI mendapatkan pengetahuan dasar IPA, memperoleh kecakapan hidup (skills of live) dalam bekerja dan berinteraksi dengan lingkungan sekitarnya, serta memiliki sikap ilmiah bagi dirinya sendiri.

\section{E. Langkah-langkah Pembelajaran IPA di SD/MI}

Guna mencapai proses dan hasil pembelajaran IPA yang optimal, maka akan ditempuh beberapa langkah-langkah pembelajaran sebagai berikut.

\section{Motivasi belajar IPA}

Motivasi bertujuan untuk membangun kekuatan mental yang menjadi penggerak belajar. Kekuatan mental berupa keinginan, perhatian, kemauan, atau cita-cita yang menjadi tujuan pembelajaran. Keinginan berhubungan dengan kebutuhan individu/siswa, ia merasa ada ketidakseimbangan antara apa yang dimiliki dan yang ia harapkan. Sebagai ilustrasi, siswa merasa bahwa ia belum memahami cara-cara menjaga dan memelihara sel, jaringan dan organ tubuhnya, maka memotivasi siswa dapat dilakukan dengan pertanyaan berikut: "Bagaimana cara menjaga dan merawat sel, jaringan dan organ pada tubuh kita?". Dari pertanyaan ini diharapkan akan tumbuh motivasi rasa ingin tahu dalam diri siswa yang dikenal sebagai motivasi internal yang bersifat instrinsik dan karena itu siswa senang melakukannya. Selain itu, motivasi eksternal juga tak luput dari perhatian guru. Motivasi eksternal ini dapat berupa 
pujian, hadiah dan lain sebagainya yang diharapkan dapat membangkitkan semangat siswa SD/MI dalam belajar IPA.

\section{Strategi pembelajaran IPA}

Salah satu upaya mengoptimalkan perubahan pengetahuan, keterampilan dan sikap ilmiah pada diri siswa adalah menggunakan pendekatan CBSA., dimana anutan pembelajaran mengarah kepada pengoptimalisasian pelibatan intelektual dan emosional siswa terhadap materi pelajaran. Dengan CBSA siswa diharapkan akan lebih mampu mengenal dan mengembangkan kapasitas belajar dan potensi yang dimilikinya secara penuh, menyadari dan dapat menggunakan sumber belajar yang terdapat disekitarnya. Selain itu siswa diharapkan lebih terlatih untuk berprakarsa, berpikir secara teratur, kritis, tanggap dan dapat menyelesaikan masalah IPA sehari-hari serta lebih trampil menggali, menjelaskan, mencari dan mengembangkan informasi yang bermakna baginya (student centered). Bila penggunaan metode CBSA cukup efektif, guru hanya bertindak sebagai pembimbing/fasilitator dalam terjadinya pengalaman belajar.

Selain pendekatan CBSA, upaya lain untuk mengembangkan kemampuan-kemampuan siswa dapat dilakukan melalui pendekatan keterampilan proses. Hal ini berdasar pada pertimbangan:

a) Pendekatan keterampilan proses memberikan kepada siswa pengertian yang tepat tentang hakekat Ilmu Pengetahuan Alam. Dengan keterampilan proses siswa dapat lebih baik mengerti fakta, prinsip dan konsep-konsep IPA.

b) Mengajar dengan keterampilan proses berarti memberikan kesempatan kepada siswa bekerja dengan Ilmu Pengetahuan Alam, sebab mereka aktif dan tidak menjadi pelajar yang pasif.

c) Menggunakan keterampilan proses untuk mengajar Ilmu Pengetahuan Alam, membuat siswa belajar proses dan prosedural IPA sekaligus.

\section{Pemilihan Metode dalam Pembelajaran IPA}

Penggunaan metode dimaksudkan untuk menunjang proses pembelajaran, sehingga dapat dijadikan sebagai alat yang efektif untuk mencapai tujuan instruksional pembelajaran. Penguasaan seorang guru terhadap berbagai metode pembelajaran sangat dimungkinkan untuk memilih beberapa metode pembelajaran yang dapat mendukung tercapainya tujuan pembelajaran IPA. Penggunaan lebih dari satu metode sangat dianjurkan dalam membelajarkan siswa. Hal ini terkait dengan kemampuan siswa menerima materi IPA berbeda-beda satu terhadap yang lainnya. Selain itu, karena setiap metode memiliki kelebihan dan kekurangan terhadap metode lainnya. Guna mendukung tujuan intruksional pembelajaran IPA, maka kombinasi metode ceramah, 
demonstrasi dan eksperimen sering digunakan bersamaan untuk menyampaikan materi pelajaran IPA. Penggunaan metode demonstrasi selalu diikuti oleh eksperimen. Dalam melakukan demonstrasi, guru selalu menjelaskan (ceramah) tahap demi tahap (biasanya suatu proses) sehingga siswa dapat mengikuti jalannya demonstrasi dengan baik. Sementara, metode eksperimen dilakukan siswa untuk mempraktikan suatu proses tersebut, setelah melihat/mengamati apa yang telah didemonstrsikan oleh guru.

Selain penggunaan metode yang tepat, pemilihan media sebagai alat bantu, mempunyai fungsi mempermudah tercapainya tujuan pembelajaran IPA. Jadi media harus mendukung isi materi pelajaran yang sifatnya fakta, prinsip, dan konsep. Media sebagai alat bantu dalam proses belajar mengajar menurut Nana Sudjana (1991) dalam (Djamarah, 2006) mempunyai fungsi:

a. Media pembelajaran, penggunaannya integral dengan tujuan dari isi pelajaran, artinya penggunaan/pemanfaatan media harus melihat kepada tujuan bahan pelajaran,

b. Penggunaan media dalam pembelajaran diutamakan untuk mempercepat proses belajar mengajar dan membantu siswa dalam menangkap pengertian dari bahan pelajaran yang diberikan oleh guru,

c. Penggunaan media dalam pembelajaran diutamakan untuk mempertinggi muatan belajar. Dengan kata lain, menggunakan media, hasil belajar yang dicapai siswa akan tahan lama diingatan siswa, sehingga mempunyai nilai tinggi.

Guna mendukung tujuan instruksional pembelajaran IPA, maka dasar pemilihan media pembelajaran adalah untuk menampilkan visualisasi obyek baik secara makro (dapat diamati dengan mata telanjang) maupun secara mikro (yang sulit diamati oleh mata telanjang misalnya sel yang merupakan bagian dari jaringan dan organ hasil pengamatan mikroskop).

\section{Penggunaan analogi sebagai media pembelajaran IPA}

Sebagai pengajar yang profesional guru dituntut agar memiliki prakarsa yang bersifat inovatif dalam hal penyampaian materi IPA di kelas. Hal ini terkait dengan keterbatasan pengetahuan siswa SD/MI dan keterbatasan media pembelajaran IPA di sekolah. Untuk mempermudah pemahaman siswa terhadap materi pelajaran IPA, salah satu cara yang dapat ditempuh oleh guru adalah menggunakan analogi-analogi sebagai media pembelajaran. Dengan analogi guru berusaha meletakkan dasardasar yang konkret dari konsep yang abstrak sehingga dapat mengurangi kesalahpahaman siswa yang bersifat verbalisme. Hal ini sangat mungkin dilakukan karena anak-anak usia SD/MI adalah individu-individu yang 
sedang berkembang dan cenderung berpikir konkret (melihat obyek berdasarkan konstruksi pengetahuan yang dimiliki sebelumnya). Sebagai ilustrasi, langkah-langkah penyajian materi IPA dapat dilakukan dengan analogi-analogi sebagai berikut:

a. Menganalogikan tubuh manusia, sama dengan sebuah bangunan gedung,

b. Jika bangunan dibentuk oleh bilik/ruang, dan letaknya sudah tertentu, maka sama halnya dengan tubuh manusia, juga dibentuk oleh organ, dan letaknya juga sudah tertentu pula,

c. Setiap bilik/ruang pada bagunan gedung dibentuk oleh dinding yang dikuatkan oleh tulang besi, maka organ manusia dibentuk oleh jaringan yang dikuatkan oleh tulang-tulang penyangga (tulang keras dan tulang rawan),

d. Dinding bangunan tersusun dari jutaan campuran butiran material pasir dan semen yang sangat halus (berukuran sangat kecil), maka jaringan tubuh manusia tersusun oleh jutaan sel yang berukuran sangat kecil dan hanya mampu dilihat dengan bantuan mikroskop.

Dari analogi-analogi yang dikemukakan di atas, diharapkan siswa dapat menarik suatu pengertian tentang sel, jaringan dan organ yang membentuk tubuh manusia. Hal ini dapat dilakukan oleh guru melalui tehnik umpan balik dengan mengajukan pertanyaan-pertanyaan lisan kepada siswa. Sebagai kesimpulan jawaban dari siswa, guru kemudian memberikan penguatan sebagai langkah meluruskan kesalahpahaman jawaban siswa terhadap pertanyaan yang diajukan.

\section{F. Evaluasi Pembelajaran IPA}

Langkah evaluasi yang diberikan kepada siswa dimaksudkan untuk mengetahui sampai dimana dan sejauh mana hasil pembelajaran yang telah dilakukan (evaluasi proses/hasil pembelajaran) dan sejauh mana tingkat penguasaan siswa tehadap bahan yang telah diberikan dalam rentang waktu tertentu (evaluasi produk/atau hasil belajar). Berkaitan dengan evaluasi proses dan produk ini, maka akan dilakukan tes dengan mengacu kepada rumusan tujuan instruksional khusus sebagaimana diilustrasikan sebelumnya dengan mengajukan pertanyaan-pertanyaan misalnya:

1. Sebutkan defenisi dari sel, jaringan dan organ pada tubuh manusia. (aspek kognitif),

2. Ceritakan langkah-langkah pengamatan sel sebagai bagian dari organ tubuh manusia dengan menggunakan mikroskop. (aspek psikomotorik) 
3. Melalui media gambar, tunjukkan tata letak organ tubuh manusia bagian dalam. (aspek afektif)

4. Sebutkan urutan komponen-komponen penyusun tubuh manusia dari ukuran yang paling kecil sampai kepada ukuran yang paling besar. (aspek kognitif)

5. Sebutkan cara menjaga dan merawat sel, jaringan dan organ pada tubuh manusia. (aspek afektif)

Evaluasi (dari butir 1 sampai butir 5) berorientasi pada perbaikan atau peningkatan kemampuan ranah-ranah kognitif, afektif dan psikomotorik siswa. Selanjutnya, dari hasil tes ini akan menjadi umpan balik bagi guru untuk mengevaluasi proses pembelajaran, bagian mana yang perlu didiagnostik dan dikembangkan.

\section{G. Kesimpulan}

Berdasarkan kajian di atas dapat disimpulkan beberapa pokok pikiran penting diantaranya adalah:

1. Ilmu Pengetahuan Alam (IPA) berhubungan dengan cara mencari tahu tentang alam secara sistematis, sehingga IPA bukan hanya penguasaan kumpulan pengetahuan yang berupa fakta-fakta, konsep-konsep, atau prinsip-prinsip saja tetapi juga merupakan suatu proses penemuan. Oleh karena itu pembelajaran IPA sebaiknya dilaksanakan secara inkuiri ilmiah (scientific inquiry) untuk menumbuhkan kemampuan berpikir, bekerja dan bersikap ilmiah serta mengkomunikasikannya sebagai aspek penting kecakapan hidup.

2. Pendidikan IPA diharapkan dapat menjadi wahana bagi peserta didik untuk mempelajari diri sendiri dan alam sekitar, serta prospek pengembangan lebih lanjut dalam menerapkannya di dalam kehidupan sehari-hari. Oleh karena itu pembelajaran IPA di SD/MI menekankan pada pemberian pengalaman belajar secara langsung melalui penggunaan dan pengembangan keterampilan proses dan sikap ilmiah.

3. Untuk meningkatkan/mengoptimalkan proses dan hasil pembelajaran IPA di SD/MI, guru diharapkan dapat memahami bagaimana cara membelajarkan IPA kepada siswa di SD/MI sehingga dapat menumbuhkan kemampuan berpikir, bekerja dan bersikap ilmiah serta dapat mengkomunikasikannya sebagai aspek penting kecakapan hidup (skills of live).

\section{H. Buku Acuan}

Cooper. James M. (1990). Classroom Teaching Skill. D.C. Heath and Company. Lexington. Massachusetts Toronto. 
Dimiyati. dkk. (2006). Belajar dan Pembelajaran. Rineka Cipta, Jakarta

Djamarah, Syaiful B. dkk. (2006). Strategi Belajar Mengajar. Rineka Cipta. Jakarta

Gagne, Robert M. dan Briggs, Leslie J. (1979). Principlse of Instructional Design. Holt Rinehart \& Winston. New York.

Gerlach, Vernon S. Ely, Donald P. (1980). Teanhing and Media A Systematile Approach. Prentice Hall Inc. New Jersey.

Joni, T. Rakaa (1980). Strategi Belajar Mengajar. P3G. Jakarta

Joni, T. Rakaa (1980). Cara Belajar Siswa Aktif, Wawasan Kependidikan dan Pembaharuan Pendidikan Guru. IKIP Malang. Malang.

Peraturan Pemerintah Republik Indonesia No. 19 Tahun 2005. (2005). Tentang Standar Nasional Pendidikan. Departemen Pendidikan Nasional. Jakarta.

Reider Duit. 2007. Science Education Researc Internationally: Conceptions, Resesearch Methods, Domain of Research. IPN-Leibniz- Institute for Science. Education, Kieb, Germany.

Saktiyono (2007). IPA Biologi untuk SMP dan MTs Kelas VII. Gelora Aksara Pratama. Jakarta.

Sanjaya, Wina (2007). Kajian Kurikulum dan Pembelajaran. Pascasarjana UPI. Bandung.

Sanjaya, Wina (2006). Strategi Pembelajaran Berorientasi Standar Proses Pendidikan, Prenada Media. Jakarta.

Sanjaya, Wina. (2006). Pembelajaran dalam Implementasi Kurikulum berbasis Kompetensi. Prenada Media. Jakarta.

Suparno, Paul (1997). Filsafat Konstruktivisme dalam Pendidikan. Kanisius. Jogyakarta.

Suryabrata, Sumadi. (2004). Psikologi Pendidikan. Raja Grafindo Persada. Joyakarta. Undang-Undang No.20 tahun 2003 (2003). Tentang Sistem Pendidikan Nasional. 